\title{
PROGNOSTIC VALUE OF INSECTICIDE TYPE AND ENZYMATIC ACTIVITIES ON SEVERITY OF ACUTE INSECTICIDES POISONING
}

\author{
Wafaa Abd El-moneim ${ }^{1 *}$, Mohamed Al-Maghraby ${ }^{2}$, Saly Yehia Abd Elhameed ${ }^{1}$, Ghada Ali Omran ${ }^{1}$, Doaa \\ Almaz ${ }^{1}$ \\ ${ }^{1}$ Department of Forensic Medicine and Clinical toxicology, Faculty of Medicine, Assiut \\ University, Assiut, Egypt. \\ 2 Department of Internal Medicine, Faculty of Medicine, Assiut University
}

\section{* Corresponding author:}

Dr. Ghada Ali Omran; Forensic Medicine \& Clinical Toxicology department; Faculty of Medicine, Assiut University, $4^{\text {th }}$ floor, section C. Assiut, Egypt;

Email: ghada_ali@hotmail.com; ghada.omran@aun.edu.eg

\begin{abstract}
Background: Insecticides poisoning is a major problem worldwide, especially in developing countries. The most extensively utilized types are pseudocholinesterase (PChE) inhibitors, predominantly organophosphorus compounds and carbamates. They are metabolized by microsomal oxidases to oxygen analogues, which are active neurotoxic metabolites. These oxygen analogues are further hydrolyzed by the serum arylesterase; paraoxonase (PON1), which appears to play a pivotal role in their detoxification. Objectives: This study aimed to 1-Identification and quantitation of common insecticides in acutely poisoned patients presented to Assiut University hospitals. 2- Detection of paraoxonase and cholinesterase levels in poisoned patients. 3- Evaluate the prognostic value of pesticide type and enzymes level in relation to the severity of insecticidal poisoning. Methods: This casecontrol study was conducted on 50 patients who have been admitted to the Emergency Unit and Intensive Care Units in Assiut University Hospitals along with 50 controls. Age, residence and sex were matched. History and clinical data and other related laboratory investigations were gathered for each patient. Blood plasma samples $(5 \mathrm{ml})$ were collected from patients on admission alongside controls then analyzed for level of pseudocholinesterase (PChE) and paraoxonase (PON1) enzymes activity by a spectrophotometer. The insecticide types were identified using Gas Chromatography/Mass spectrometry (GC-MS). Results: The patients were mostly males, of young age group and residing in rural areas. The mode of poisoning was mainly accidental by oral route $(66 \%)$. Tachycardia, tachypnea and hypotension were most commonly presenting muscarinic signs. The detected insecticides were mainly of the organophosphate types specifically malathion. A highly significant decrease in PChE and PON1 level were detected in patients compared to controls that the decline in their levels was also significantly associated with the severity of acute poisoning. A positive correlation was also observed between PChE and PON1 levels. Conclusion: the present study identified more than one type of pesticides mainly of organophosphate category among acutely poisoned patients. Furthermore, it pointed to those persons with higher paraoxonase activity and less cholinesterase inhibition may have a better chance of toxic effects amelioration.
\end{abstract}

Keywords: Insecticides; Cholinesterase, Paraoxonase, GC/MS. 


\section{INTRODUCTION}

The most common pesticides causing human poisoning were the cholinesterase enzyme inhibitors as organophosphorus compounds (OPs) \& carbamates (Zhang et al., 2011, Mandour, 2013). Organochlorine (OC) pesticides are synthetic pesticides widely used all over the world. They belong to the group of chlorinated hydrocarbon derivatives, which have huge application in the chemical industry and in agriculture though previously banned in developed countries. These compounds are recognized for their high toxicity, slow degradation and bioaccumulation (Jayaraj et al., 2016).

Acute organophosphorus poisoning is a significant cause for morbidity and mortality worldwide, affected about 3,000,000 person during 2002-2005 (Kishi, 2012, Soltaninejad and Shadnia, 2014). In developing countries, OP poisoning causes more deaths than infectious diseases especially among farmers and occupational workers (McCauley et al., 2006).

Human studies provided evidence that low PON1 level may increase susceptibility to toxic effects of certain insecticides. However, it is still uncertain whether PON1 status can play a significant role at lower dose levels of exposure (Hofmann et al., 2009, Matthews et al., 2011, Costa et al., 2013). It was reported that high levels of PON1 protect individuals against acute OP poisoning (Ginsberg et al., 2009, Darwish et al., 2017). It was also unclear if there was a relationship between the level of pseudocholinesterase (PChE), paraoxonase activity along with its polymorphism, and the severity of insecticides poisoning (Brahmi et al., 2006, Hofmann et al., 2009). Other previous studies reported that patients with higher paraoxonase1 activity may have a better chance of ameliorating the lethal effect of acute organophosphate poisoning (Richard et al., 2013).

Sözmen et al. (2002) and Hofmann et al. (2009) they found that PON1 activity was lower among OPs poisoned patients with low cholinesterase activity upon hospital admission relative to subjects with higher cholinesterase activity. Also Akgür et al. (2003) found positive correlation between PChE and PON1 activities in a study of agricultural male workers suffering OPs poisoning in Turkey. The same result reported by Rahul et al. (2017) in studies undertaken in South India in OPs poisoned patients. Until now, measurement of serum cholinesterase has been considered as the most specific test for OP poisoning. However, studies in animal models had demonstrated high-density lipoprotein associated paraoxonase (PON1) as one of the essential determinants of an individual's sensitivity to some OP insecticides. Despite having convincing evidence in animal models, very few epidemiological studies had examined PON status as a determinant of severity of acute OP poisoning, further research can be done to investigate the same in human. This case-control study aimed to identify and quantity the common insecticides causing acute poisoning in patients in Assiut and nearby governments presented to Assiut University Hospitals in upper Egypt. The measurement of paraoxonase and pseudocholinesterase plasma levels and their relationship with the severity of insecticidal poisoning were other vital objectives.

\section{Patients and methods}

This case-control study was conducted on 50 patients who have been admitted to the Emergency Unit and Intensive Care Units in Assiut University Hospitals, versus matched 50 controls.

(A) Patients: Patients included in this study were adults acutely exposed to insecticidal poisoning. Included patients with any pre-existing atherosclerosis, coronary artery disease, liver disease, kidney disease, Parkinson disease, bronchial asthma, diabetes, tumors and pregnancy were excluded. Written informed consent was obtained from each patient in accordance with the protocol approved by the Medical Ethical Committee of the Faculty of Medicine, Assiut University. Fifty adult patients had participated in the 
study as a control group. They were matched for sociodemographic criteria (age, sex \& residence).

Diagnosis of acute pesticidal poisoning was based on history of pesticidal exposure, characteristic symptoms and signs. There are four primary vital signs including: body temperature, blood pressure, pulse (heart rate), and breathing rate (respiratory rate). Hypotension is defined by SBP of $90 \mathrm{~mm} \mathrm{Hg}$ or lower; hypertension by SBP above $140 \mathrm{~mm}$ $\mathrm{Hg}$; bradycardia by an HR below 60 beats per minute, and tachycardia by a HR of 100 beats per minute or higher. The sociodemographic data (age, sex, $\&$ residence) were registered as well. The severity of poisoning had been assessed according to symptoms and signs which were adopted by Sam et al. (2009) and Cotton et al. (2015).

The severity of symptoms and signs of acute OP was graded into:

(I) Mild: Mild, transient, and spontaneously resolving symptoms and signs as: nausea, vomiting, diarrhea, salivation/lacrimation, bronchoconstriction, increased bronchial secretion, bradycardia, headache, dizziness and /or diaphoresis.

(II) Moderate: Pronounced or prolonged symptoms and signs as: the same as above plus miosis, urinary/fecal incontinence, fine muscle twitching, dysarthria, ataxia, confusion, anxiety, bradycardia and cramps.

(III) Severe: Severe or life-threatening symptoms and signs. They are characterized the same as above plus: bronchospasm, increased bronchial secretion, dysarthria, ataxia, coma convulsions, respiratory failure, loss of consciousness and coma.

(B) Methods: Venous blood sample $(5 \mathrm{ml})$ were collected in K3EDTA tubes from all studied subjects immediately after admission and before administration of any medication. Centrifugation was performed at $1500 \mathrm{rpm}$ for $15 \mathrm{~min}$ within $1 \mathrm{~h}$ after collection. The separated plasma was kept in Eppendorf tubes, given serial numbers and stored at or below $20^{\circ} \mathrm{C}$ for biochemical analyses (paraoxonase and psuedocholinesterase activities).

Pseudocholinesterase (PChE) enzyme activities were determined by using pharmacia LKB Ultraspec III Spectrophotometer and a commercial kit (Chema Diagnostica Kit for analytical cholinesterase FL (DGKC) kinetic colorimetric method) (Chema / Italy) according to instructions included.

Paraoxonase enzyme activity was measured by the spectrophotometer using the synthetic substrate phenyl acetate (Alfa/Germany) according to Dantoine et al. (1998).

Identification of the pesticides using Gas Chromatography/Mass spectrometry (GC-MS) was conducted according to an internally validated method developed within the Analytical Chemistry Accredited laboratory (ACAL) of the Faculty of Science, Assiut University.

Each sample was extracted with $1 \mathrm{ml}$ of hexane then centrifugated for $10 \mathrm{~min}$ at $10 \mathrm{C}^{\circ}$. The clear organic layer was collected and $2 \mu \mathrm{L}$ was injected into GC-MS (7890A-5975B)( Agilent, USA) under the following conditions; analytical column used was DB-5ms $(30 \mathrm{~m}, 0.25 \mathrm{~mm}, 0.25 \mu \mathrm{m})$, and the initial temperature was $90^{\circ} \mathrm{C}$ hold for $4 \mathrm{~min}$ increased by rate $30^{\circ} \mathrm{C}$ for $4 \mathrm{~min}$ to $180^{\circ} \mathrm{C}$ for $0 \mathrm{~min}$, then increased by rate $4^{\circ} \mathrm{C} / \mathrm{min}$ to $270^{\circ} \mathrm{C}$ for $0 \mathrm{~min}$, then $30^{\circ} \mathrm{C} / \mathrm{min}$ to $280^{\circ} \mathrm{C} / \mathrm{min}$ hold for $7 \mathrm{~min}$. The post run $3 \mathrm{~min}$ at $260^{\circ} \mathrm{C}$. The volume of injected sample was $2 \mu \mathrm{L}$ in splittless mode. The injector temperature was set at $250^{\circ} \mathrm{C}$. Helium $(99.999 \%$, purity) was used as a carrier gas with ramped flow $1 \mathrm{ml} /$ min. The total run time was $36.833 \mathrm{~min}$.

Statistical analysis: Results were
tabulated and statistical analysis was
performed with aid of the Statistical Package
for the Social Science (SPSS) version 20.
Association analysis of categorical data were
undertaken using Chi square for 2 groups.
Comparison between more than 2 sets of non-
parametric data was performed via Kruskal


Wallis test. Correlations between enzymes levels was evaluated using Pearson s correlation. The level of statistical significance was set at $\mathrm{p}$ value below 0.05 .

\section{RESULTS}

This case-control study was performed according to the predetermined criteria and admitted for acute insecticidal poisoning management.

\section{Sociodemographic data}

Fig. (1) showed age distribution among studied patients. Most of patients were in the age group from 20 to 35 years. Males outnumbered females with a sex ratio of $4: 1$. Residence of rural areas accounted for more than half of the patients $(64 \%)$.

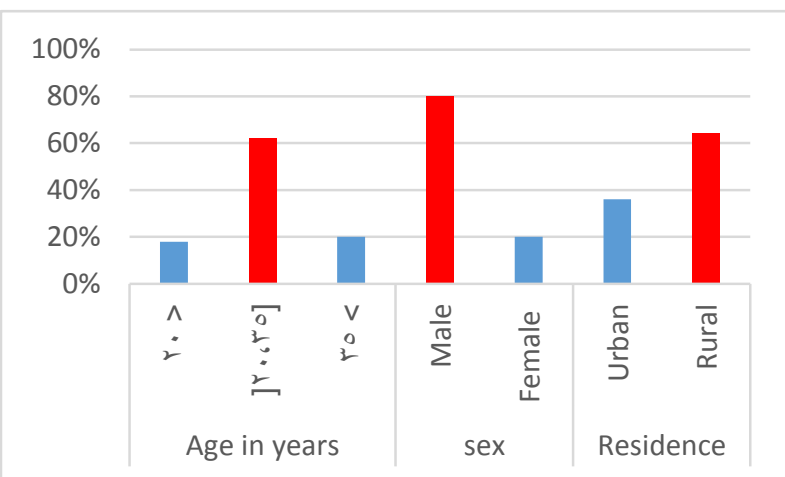

Fig. (1): Sociodemographic data of poisoned patients as regard age, sex and residence.

\section{Route and Manner of poisoning}

Most patients were accidentally poisoned $(90 \%)$. Oral route significantly outnumbered other routes (60\%) as shown in Fig. (2).

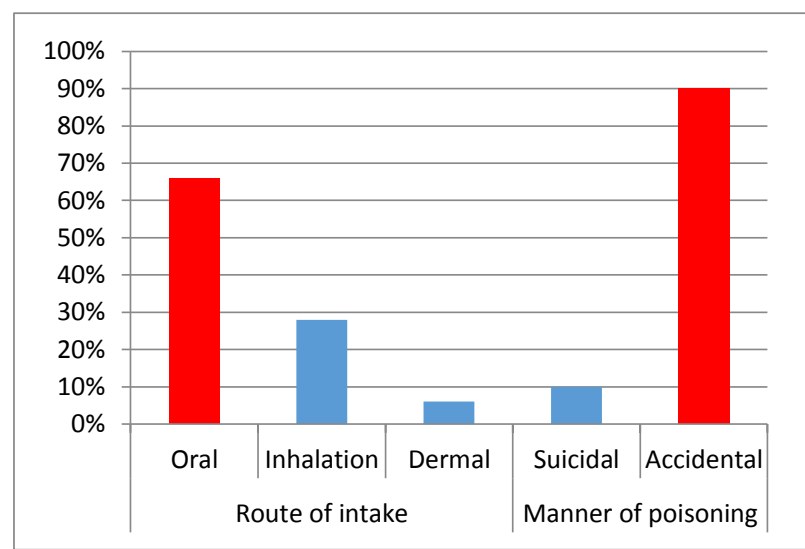

Fig. (2): Route of intake and manner of poisoning among poisoned patients.

\section{Clinical findings on admission}

\section{A-Vital signs}

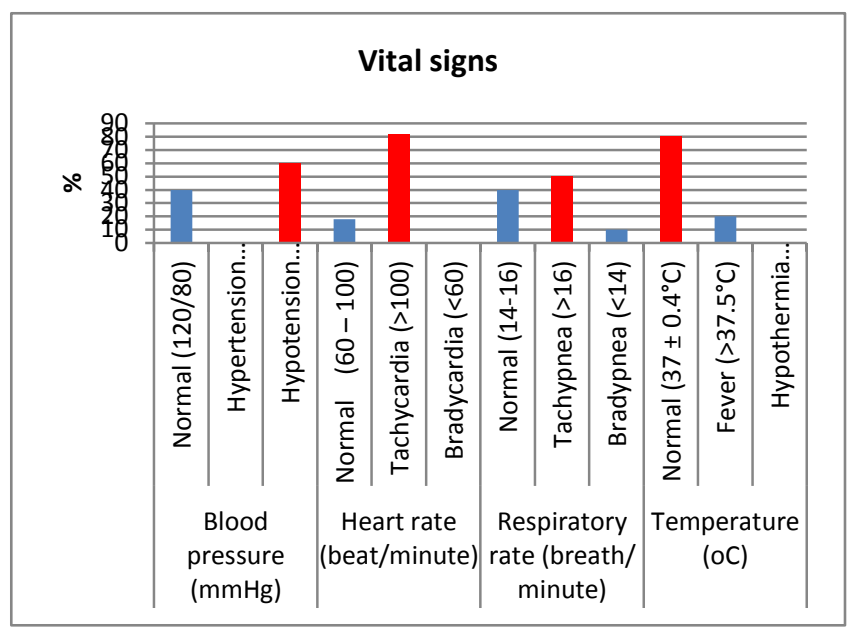

Fig. (3): Vital signs observed among poisoned patients.

Fig. (3) showed that $60 \%$ of patients in the present study presented with hypotension, $82 \%$ had tachycardia and $50 \%$ of patients presented with tachypnea. Most of patients $(80 \%)$ had normal body temperature, but only $20 \%$ had hyperthermia.

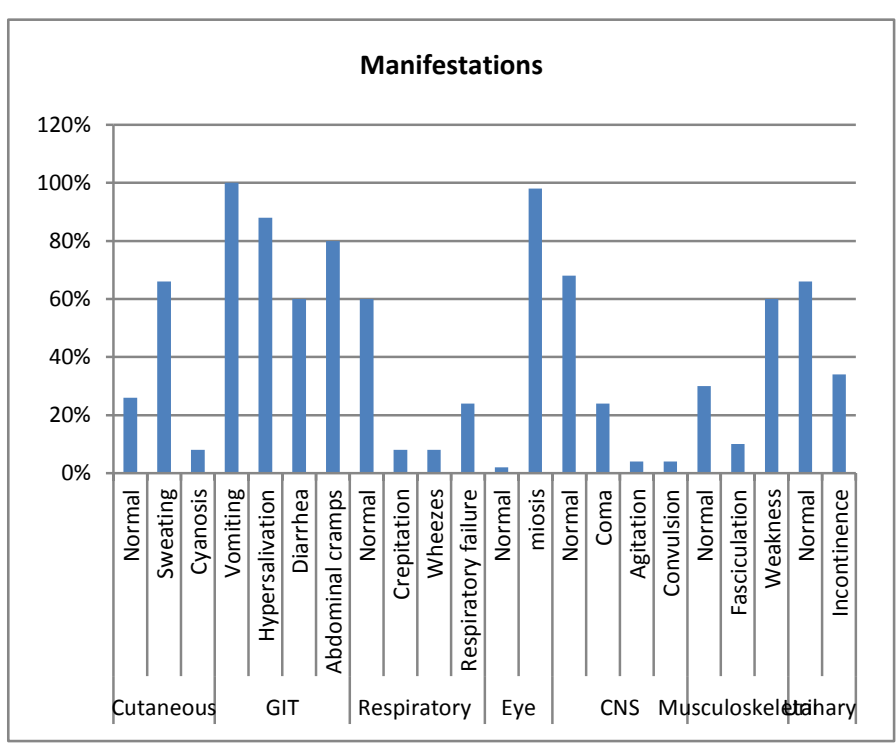

Fig. (4): Nicotinic \& muscarinic manifestations developed among poisoned patients.

Fig. (4) showed the presenting nicotinic \& muscarinic manifestations developed among 
studied patients was vomiting as the most frequent GIT symptom followed by pupil constriction which occurred in $98 \%$ of patients. Sweating was obvious in most patients. The respiratory manifestations ranged between crepitation and wheezes in $8 \%$, and respiratory failure in $24 \%$ of patients in the current study. Concerning CNS manifestations, they affected minor percentages of patients in the form of coma, agitation and convulsions. A considerable percentage of patients presented with muscle weakness. CVS manifestations were mostly in the form of shock with a major category suffered tachycardia. Urinary incontinence was observed in $34 \%$ of patients.

\section{Types of insecticides}

Gas chromatography/mass spectrophotometery was used to determine the type of insecticidal compound among poisoned patients (Table 1). The organophosphate category $(68 \%)$ constituted the highest percentage detected either single or mixed. The organophosphate malathion (64\%), parathion $(44 \%)$ constituted the uppermost percentages among the poisoned patients. Ingested products were found mainly mixed with only pure malathion toxicity in 6 cases and parathion in 2 cases. Also, we found other members of organochlorine category $(32 \%)$. The unexpected organochlorine herbicide (propachlor) were found mixed with other insecticides in a relatively large percentage of patients $(52 \%)$. The latter was not included in further statistical analysis as it was out of scope of this work. Still, other insecticidal organochlorines as hexachlorobenzene were detected as shown in Table (1). Table (2) showed a significant increase level of malathion with increasing poisoning severity mainly in mild and moderate cases which constituted the main portion of patients.
Table (1): Insecticide analysis done by (GC/MS) among poisoned patients.

\begin{tabular}{|c|c|c|}
\hline $\begin{array}{l}\text { Insecticides with their } \\
\text { generic names }\end{array}$ & \multicolumn{2}{|r|}{$\mathrm{n}=50(\%)$} \\
\hline $\begin{array}{l}\text { Organophosphate (OPs) } \\
\text { insecticides }\end{array}$ & \multicolumn{2}{|r|}{$34(68 \%)$} \\
\hline Single & $8(23.5 \%)$ & $\begin{array}{l}\text { Malathion } 6(75 \%) \\
\text { Parathion 2(25\%) }\end{array}$ \\
\hline $\begin{array}{l}\text { Mixed (Malathion with } \\
\text { other types of OPs as: } \\
\text { Parathion, Chlorpyrifos } \\
\text { Parathion methyl, Ethion) }\end{array}$ & $26(67.5 \%)$ & $\begin{array}{c}\text { Malathion 26(100\%), } \\
\text { Parathion } \\
\text { 20(76.9\%),Chlorpyrifos } \\
\text { 18(69.2), Parathion Ethyl } \\
\text { 6(23.1\%), Ethion 4(15.4\%) }\end{array}$ \\
\hline $\begin{array}{l}\text { Organochlorine }(\mathrm{OC}) \\
\text { insecticides }\end{array}$ & \multicolumn{2}{|r|}{$16(32 \%)$} \\
\hline Single & \multicolumn{2}{|r|}{-------- } \\
\hline $\begin{array}{l}\text { Mixed } \\
\text { (Hexachlorobenzene with } \\
\text { other types of OC as } \\
\text { :Heptachlor epoxide and } \\
\text { Lindane) }\end{array}$ & $16(32 \%)$ & $\begin{array}{c}\text { Hexachlorobenzene } 16(100 \%) \\
\text { Heptachlor epoxide } 2(12.5 \%) \\
\text { and Lindane } 6(37.5 \%)\end{array}$ \\
\hline $\begin{array}{l}\text { Unexpected non- } \\
\text { insecticidal } \\
\text { organochlorines } \\
\text { (propachlor) } \\
\end{array}$ & \multicolumn{2}{|r|}{$26(52 \%)$} \\
\hline Single & & 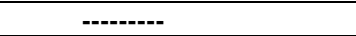 \\
\hline $\begin{array}{l}\text { Mixed propachlor with } \\
\text { Organophosphate (OPs) } \\
\text { insecticides }\end{array}$ & \multicolumn{2}{|r|}{$20(76.9 \%)$} \\
\hline $\begin{array}{l}\text { Mixed propachlor with } \\
\text { Organochlorine (OC) } \\
\text { insecticides }\end{array}$ & & $6(23.1 \%)$ \\
\hline
\end{tabular}

$n:$ number and percentage (\%).

Table (2): Statistical analysis of insecticides types versus degree of severity among poisoned patients.

\begin{tabular}{|c|c|c|c|c|}
\hline \multirow{3}{*}{ Type } & \multicolumn{4}{|c|}{ Degree } \\
\hline & Mild (N=6) & $\begin{array}{c}\text { Moderate } \\
(\mathrm{N}=32)\end{array}$ & $\begin{array}{l}\text { Severe } \\
(\mathrm{N}=12)\end{array}$ & \multirow{2}{*}{$\begin{array}{c}\mathbf{P} \\
\text { value }\end{array}$} \\
\hline & \multicolumn{3}{|c|}{ Concentration (Median, $25^{5 \mathrm{~h}}-75^{5 \mathrm{~h}}$ ) } & \\
\hline $\begin{array}{l}\text { Hexachlorobenzene } \\
(\mu \mathrm{g} / \mathrm{mL})\end{array}$ & $5.33(0-5.33)$ & $5.12(0-5.12)$ & $\begin{array}{l}5.55(0- \\
5.55) \\
\end{array}$ & 0.215 \\
\hline Malathion $(\mu \mathrm{g} / \mathrm{mL})$ & $\begin{array}{c}1.34(0.73- \\
2.74)\end{array}$ & $\begin{array}{c}2.08(0.11 \text { - } \\
4.18)\end{array}$ & $\begin{array}{c}0.05(0- \\
1.06) \\
\end{array}$ & $0.046 *$ \\
\hline Chloropyrifos $(\mu \mathrm{g} / \mathrm{mL})$ & $2.9(0-2.9)$ & $2.5(0-2.5)$ & $3.2(0-3.2)$ & 0.113 \\
\hline Parathion $(\mu \mathrm{g} / \mathrm{mL})$ & $1.3(0-1.3)$ & $1.7(0-1.7)$ & $2.1(0-2.1)$ & 0.506 \\
\hline
\end{tabular}

$P>0.05$ : non significant ; $P<0.05$ : significant, 25 th $-75^{\text {th }}$ are percentiles, n:number.

\section{Pseudocholinesterase (PChE) and paraoxonase (PON) levels}

Student t-test analysis showed a significant difference as regard pseudocholinesterase and paraoxonase levels in patients and controls (Table 3 ). The mean \pm SD levels of PChE in patients was 
$2281.76 \pm 1109.39$, significantly lower than that of controls 7608 \pm 969.29 . Mean levels of paraoxonase in patients and controls were $29.84 \pm 4.64$ and $105.37 \pm 33.31$ respectively.

Table (3): Statistical analysis of the difference of pseudocholinesterase and paraoxonase levels in patient and control groups using student t-test.

\begin{tabular}{|c|c|c|c|c|}
\hline \multirow{2}{*}{ Enzymes } & $\begin{array}{c}\text { Patient } \\
\mathbf{n = 5 0}\end{array}$ & $\begin{array}{c}\text { Control } \\
\mathbf{n = 5 0}\end{array}$ & \multirow{2}{*}{$\mathbf{t}$} & P-value \\
\cline { 2 - 4 } & \multicolumn{2}{|c|}{ Mean $\pm \mathrm{SD}$} & & \\
\hline $\begin{array}{c}\text { Pseudocholineste } \\
\text { rase U/l }\end{array}$ & $2281.76 \pm 1109.39$ & $7608 \pm 969.29$ & -25.57 & $<0.001^{* * *}$ \\
\hline $\begin{array}{c}\text { Paraoxonase } \\
\mathbf{I U} / \mathbf{m L}\end{array}$ & $29.84 \pm 4.64$ & $105.37 \pm 33.31$ & -15.723 & $<0.001^{* * *}$ \\
\hline
\end{tabular}

*** $p<0.001$ highly significant; $n:$ number.

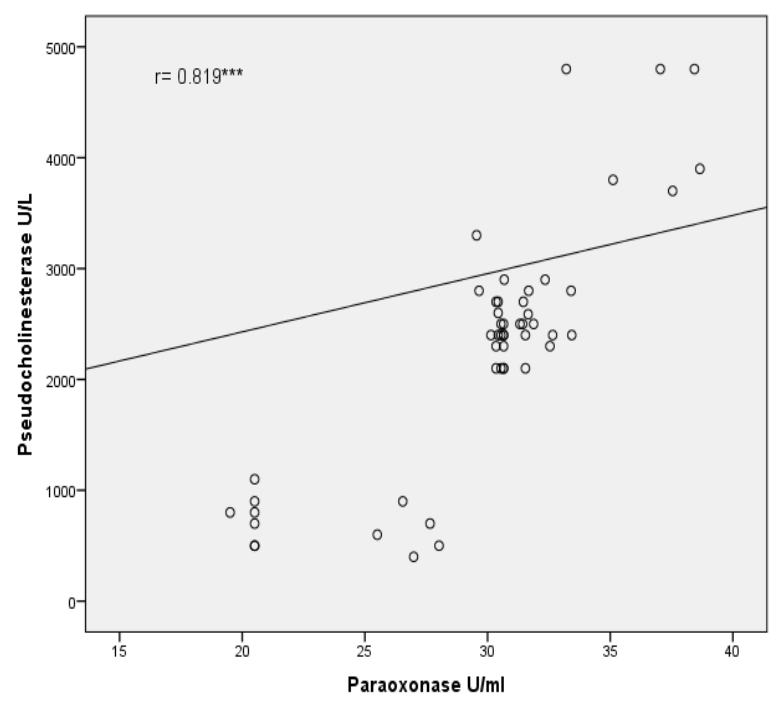

Fig. (5): Correlation between pseudocholinesterase and paraoxonase enzymes levels in poisoned patients.

Pearson's correlation was examined and a highly significant strong positive correlation was found between paraoxonase and pseudocholinesterase levels in poisoned patients $(\mathrm{r}=0.851)$ (Fig. 5). The individuals with lower PON1 activity also had lower cholinesterase activity, suggesting the inhibition of cholinesterase by insecticides. In contrast, individuals with higher PON1 activity had higher cholinesterase activity, indicating the involvement of PON1 in detoxification of insecticides.
Table (4): Analysis of the levels of paraoxonase and pseudocholinesterase with the severity of symptoms developed among patients under the study.

\begin{tabular}{|c|c|c|c|c|c|c|c|}
\hline & & Mild & \begin{tabular}{|c} 
Mod \\
erat \\
e
\end{tabular} & $\begin{array}{c}\text { Seve } \\
\text { re }\end{array}$ & $\begin{array}{c}\text { Tota } \\
1\end{array}$ & \multirow[t]{2}{*}{$\mathrm{X}^{2}$} & \\
\hline & & $n o=6$ & $\begin{array}{c}\text { no= }= \\
32\end{array}$ & $\begin{array}{c}\text { no= } \\
12 \\
\end{array}$ & $\begin{array}{c}\text { no= } \\
50\end{array}$ & & ue \\
\hline \multirow{2}{*}{$\begin{array}{c}\text { Paraox } \\
\text { onase } \\
(\mathrm{U} / \mathrm{mL})\end{array}$} & $\begin{array}{l}\text { Low } \\
\text { level }\end{array}$ & $\begin{array}{c}5 \\
(83.3 \\
\%)\end{array}$ & $\begin{array}{c}32 \\
(100 \\
\%)\end{array}$ & $\begin{array}{c}12 \\
(100 \\
\%)\end{array}$ & $\begin{array}{l}49 \\
(98 \\
\%) \\
\end{array}$ & \multirow{2}{*}{$\begin{array}{l}7.4 \\
83\end{array}$} & \multirow{2}{*}{$\begin{array}{l}0.0 \\
24^{*}\end{array}$} \\
\hline & $\begin{array}{c}\text { Nor } \\
\text { mal } \\
\text { level }\end{array}$ & $\begin{array}{c}1(16.7 \\
\%)\end{array}$ & - & - & $\begin{array}{l}1(2 \\
\%)\end{array}$ & & \\
\hline \multirow{2}{*}{$\begin{array}{c}\text { Pseudo } \\
\text { choline } \\
\text { stease } \\
\text { (U/L) }\end{array}$} & $\begin{array}{l}\text { Low } \\
\text { level }\end{array}$ & $\begin{array}{c}3 \\
(50 \%)\end{array}$ & \begin{tabular}{|c}
31 \\
$(96$. \\
$9 \%)$ \\
\end{tabular} & $\begin{array}{c}12 \\
(100 \\
\%) \\
\end{array}$ & $\begin{array}{l}46 \\
(92 \\
\%) \\
\end{array}$ & \multirow{2}{*}{$\begin{array}{c}6 . \\
15 \\
7\end{array}$} & 0.0 \\
\hline & $\begin{array}{c}\text { Nor } \\
\text { mal } \\
\text { level }\end{array}$ & $\begin{array}{c}3 \\
(50 \%)\end{array}$ & $\begin{array}{c}1 \\
(3.1 \\
\%) \\
\end{array}$ & - & $\begin{array}{l}4(8 \\
\%)\end{array}$ & & $*$ \\
\hline
\end{tabular}

X2 Chi-square statistical analysis test; ${ }^{*} P$ $<0.05$ : significant; $* * \quad p<0.001$ highly significant

Table (4) showing that there was significant association between development of symptoms and level of paraoxonase and pseudocholinesterase in patients. Paraoxonase (PON1) activity in mild cases was significantly higher than moderate and sever cases, indicating a protective effect of PON1 against insecticides toxicity.

\section{DISCUSSION}

Despite the great development in the intensive care management, ingestion of insecticidal compounds is still a greatly contributing agent of poisoning with high mortality rates, so it is important to estimate the severity and prognosis of the patients who were intoxicated by these agents (Lee et al., 2013). This case-control study was performed to detect causative insecticides and to evaluate pseudocholinesterase and paraoxonase (PON1) 
enzyme activities as diagnostic tools in acute insecticidal exposure and relation to poisoning severity assessment.

Results obtained in this study, revealed that $62 \%$ of patients were of young working age group (20-35 years). This finding was in accordance with Gannur et al. (2008), Shah Harsh et al. (2012), Ahmed et al. (2014) and Banday et al. (2015) in which the incidence was highest in patients aged less than 40 years. Poisoning were more in rural areas, that could be explained by low insecticidal cost with misuse and lack of protective devices (Magauzi et al., 2011, Mishra et al., 2012, Banday et al., 2015). These findings were in the accordance with other studies (Gannur et al., 2008, Patel and Tekade, 2011, Hassan and Madboly, 2013, Ahmed et al., 2014, Bilal et al., 2014). Most were accidently poisoned while the remaining were intoxicated intentionally, due to consumption of food items containing insecticide residues or due to faulty or missing protective equipment and lack of knowledge about the danger of insecticides. These results agreed with Mandour (2013) and Damalas and Koutroubas (2016).

In the present study $80 \%$ of patients were males due to easy availability of OPs in agriculture fields and strains in male than female. This was in agreement with many studies as Jayawardane et al. (2008), Ahmed et al. (2014), Sumathi et al. (2014) and Z'gambo et al. (2016). While this disagree with Banerjee et al. (2012); Hassan and Madboly (2013) and (Gunduz et al., 2015) who reported that females were affected more than males due to emotional liability of females to life stresses and strains in our society than males along with easy availability of OPs at home (Z'gambo et al., 2016).

All patients in the current study were classified based on severity of symptoms according to Sam et al. (2009) and Cotton et al. (2015); most of cases were of moderate category. The classification of degree of poisoning severity according to clinical symptoms (not level of PChE enzyme) was reported to be more reliable with better correlations in line with Akdur et al. (2010), Sam et al. (2009) and Elgohary et al. (2013). As Brahmi et al. (2006) found no signs of severity in spite of decrease of cholinesterase levels in his patients, and explained this by the presence of genetic variations. As PChE activity does not relate to severity of poisoning, it can be used as a sensitive marker of exposure to most organophosphorus compounds or other cholinesterase-inhibiting compounds (Eddleston et al., 2007). In contrast Mandour (2013) found that classification of poisoning according to the level of PChE enzyme was more reliable.

In the present study most of patients were exposed to the insecticides by the oral route. This is due to easy ingestion of poisons by mouth especially with liquid consistency of insecticides (Coskun et al., 2015). Lack of knowledge in dealing with these products may play a significant role in exposure to these compounds through dermal and inhalation routes (Bilal et al., 2014, Coskun et al., 2015). This agreed with the results of many studies (Bilal et al., 2014, Colak et al., 2014, Priyadarsini et al., 2015).

As regard the vital signs, most of patients in the present study had hypotension which occur due to muscarinic effects on the heart and this finding is strongly associated with mortality. As regard heart rate, symptoms like tachycardia observed in current work, which sometime occur with acute insecticidal toxicity are most likely due to excessive cholinergic nicotinic effects on the CNS, then may be followed by bradycardia due to parasympathetic stimulation which was more frequent in patients with delayed presentation to the hospital (Vijayakumar et al., 2011, Peter et al., 2014, Gunduz et al., 2015). Fifty percent of patients presented with tachypnea. Respiratory system affection is the mostly presented in OP poisoning. Central effects lead to respiratory depression (Kavya et al., 2012, Peter et al., 2014). In studies done by Rehiman et al. (2008) and Banerjee et al. 
(2012) tachypnea was found in $35 \%$ of patients.

In the current study most of patients had normal temperature. This was in contrast to the study done by Moffatt et al. (2010) in which there was initial hypothermia affecting most OPs poisoned patients in a rural hospital in Polonnaruwa, Sri Lanka. Initial hypothermia was followed by a period of normal to high body temperature, this may be due to drug administration as atropine, convulsion or agitation and the use of physical restraint (Moffatt et al., 2010).

Muscarinic manifestations were the most common in the form of vomiting, constricted pupil, salivation, abdominal cramps and sweating. As regard nicotinic manifestations included, muscle weakness and fasciculations were observed. CNS affection in the current study was in the form of agitation, coma and convulsion. This was in agreement with many studies in which muscarinic manifestations were the most common (Lee et al., 2013, Peter et al., 2014). Vomiting was the most common symptom as reported by Hassan and Madboly (2013) Colak et al. (2014) Tripathi (2014) and Banerjee et al. (2012). Banday et al. (2015) observed that miosis was the most presenting manifestation $(93.2 \%)$ followed by increased salivation $(68.4 \%)$.

Considering the GC/MS results, the most accused substance was organophosphorus compounds (68\%) followed by organochlorines (32\%). Products or active substances which contributed to intoxications were mostly mixed and toxicity caused by more than one chemical agent. There are many commercially available pesticides that include certain organometallic and many older organochlorine compounds that are also toxic and persistent. The latter had been banned from use in many countries in the 1970s and 1980s, so exposure to these compounds had been decreased ever since. However, these chemicals are highly persistent and small amounts are still present in the environment as they enter in contents of many pesticides (Damalas and Koutroubas, 2016). Mixed toxicity of insecticides was important to detect as toxicity of some organophosphates can be potentiated by other organophosphates or by previous exposure to organochlorines; high level of propachlor or other organochlorines may be due to previous exposure (Hernández et al., 2008). This delicate analysis was necessary as all patients in the present study couldn't determine the type of the insecticide agent but GC/MS could exactly determine that.

Jørs et al. (2006) in Bolivia found that OPs constituted the group of pesticides more frequently used by $88 \%$ of the farmers. The presence of organochlorines (as propachlor) which is prohibited pesticides, their presence reveals the existence of sources for the informal provision of pesticides, opening the door to increased risks of poisoning. This was in agreement with a previous study conducted in Japan that reported 10 deaths out of 63 cases of insecticidal exposure to malathion, as well as 404 deaths out of 480 cases of malathion-associated suicides or homicides. Other accidental death from malathion toxicity in human population has also been documented (Paul et al., 2003). The highest concentrations of malathion and chlorpyrifos were detected in human plasma as those organophosphates were among the list of Thailand's highly imported pesticides (Panuwet et al., 2009), also the same with Rahul et al. (2017) in his study in south India. Additionally, Kerkvliet and Lawrence (2010) reported that malathion have been reported to have much higher toxicity due to the presence of contaminants. This was in contrast with Bey et al. (2001) and Mandour (2013) who reported that all their cases are of parathion insecticide by $\mathrm{GC}$ analysis.

There is marked phosphorylation of $\mathrm{PChE}$ under the influence of the high dose of OP exposure in a very short time. This was in agreement with other reports (Jokanović and Stojiljković, 2006, Balali-Mood and BalaliMood, 2008). Depression of PChE activity in the blood was proved as a validated biomarker of organophosphate pesticide exposure and is 
used to monitor occupational exposures as well (Timchalk, 2010). The predominance of the OPs in this study showed the importance of monitoring the activity of cholinesterase, as the main biomarker of poisoning with OPs.

Amanvermez et al. (2010) Muley et al. (2014) and Tripathi (2014) studies were in line the current study as regard the associated relation between the severity and PChE level. There was a significant relation between low PChE level and bad prognosis.

Paraoxonase enzyme (PON1) in the current study was significantly related to the severity of illness as well. There was an inhibition in PON1 level in patients as compared to controls. This finding was consistent with Sözmen et al. (2002). PON1 can hydrolyze the oxygen analougs of OPs and it is significant in OP detoxification process (Richard et al., 2013). Conversely, Tanrisev and Toprak (2004) didn't report any significant difference in PON1 activity in acutely OPs poisoned patients. The insecticides induced decrease in PON1 activity may be due to direct inhibition without affecting enzyme synthesis or clearance or due to competitive effect of the inebriating insecticides during the in vitro assay (Sözmen et al., 2002, Hernández et al., 2008).

The existing study displayed significant positive correlation between PChE and PON1 enzymes activity in patients of this study. This finding showed consistency with study carried out by Akgür et al. (2003) and Araoud et al. (2010). Also this paralleled the results of Sözmen et al. (2002) Hofmann et al. (2009), Austin et al. (2008) and Parul et al. (2012), as they found that PON1 activity was lower among subjects with low cholinesterase activity upon hospital admission relative to subjects with higher cholinesterase activity. PON1 can hydrolyze several OPs oxon derivatives (active form of OPs), thereby, preventing ChE from inhibition by OPs. At the same time, paraoxonase enzyme may protect the RBCs membrane from lipid peroxidation through its antioxidant properties (Eskenazi et al., 2010). So, it may decrease or limits the degree of ChE inhibition. Conversely, Akgür et al. (2003) demonstrated lack of correlation, it could be attributed to high acute organophosphate exposure that gave little chance for paraoxonases to provide much protection than low level chronic exposure, where additional time for enzymatic detoxification is available.

\section{CONCLUSION}

Insecticidal poisoning is considered severe clinical entity and cause considerable toxicity. The prevalence of insecticides intoxication was mainly in males of young age, which be attributed to occupational exposure, lack of experience, unsafe attitudes, faulty sprayers, lack of protective equipment. Hypotension and bradypnea in patients with OPs toxicity were more associated with high grade of severity. The present study identified over one type of pesticides mainly of organophosphate category among acutely poisoned patients with a considerable prevalence of organochlorines. Our study suggests that patients with higher paraoxonase 1 activity may have a better chance of detoxifying the poisoning effects of insecticides and may have a positive effect on survival. Preventive strategies should be adopted to compact the still prevalent type of banned pesticides especially organochlorine compounds such as propachlor. Further studies on the protective effect of paroxonase and its potential therapeutic role in management of severe insecticidal poisoning might be mandatory in the near future. Pesticide monitoring programs should be implemented in rural areas to assure safety and protective measures applied.

\section{REFERENCES}

Ahmed, K. M.; Sainath, C. \& Ahmed, P. (2014): A Cross Sectional Study of estimation of Plasma Pseudo cholinesterase and its Correlation to mortality among organophosphorous poisoning patients. Indian Journal of Basic 
and Applied Medical Research, 3, 285291.

Akdur, O.; Durukan, P.; Ozkan, S.; Avsarogullari, L.; Vardar, A.; Kavalci, C. \& Ikizceli, I. (2010): Poisoning severity score, Glasgow coma scale, corrected QT interval in acute organophosphate poisoning. Human \& experimental toxicology, 29, 419-425.

Akgür, S.; Öztürk, P.; Solak, I.; Moral, A. \& Ege, B. (2003): Human serum paraoxonase (PON1) activity in acute organophosphorous insecticide poisoning. Forensic science international, 133, 136140.

Amanvermez, R.; Kilic, E.; Kefeli, M.; Polat, C. \& Gunay, M. (2010): Protective effects of etanercept and methylprednisolone on pancreatic damage in cerulein-induced acute pancreatitis. Saudi medical journal, 31, 394-399.

Araoud, M.; Neffeti, F.; Douki, W.; Najjar, M. F. \& Kenani, A. (2010): Paraoxonase 1 correlates with butyrylcholinesterase and gamma glutamyl transferase in workers chronically exposed to pesticides. Journal of occupational health, 52, 383388.

Austin, J. F.; Horke, S.; Haines, D. C.; Chowdhary, P. K.; Xiao, J.; Kramer, G. L.; Haley, R. W. \& Draganov, D. I. (2008): Dominant role of paraoxonases in inactivation of the Pseudomonas aeruginosa quorum-sensing signal $\mathrm{N}-(3-$ oxododecanoyl)-L-homoserine lactone. Infection and immunity, 76, 2512-2519.

Balali-Mood, M. \& Balali-Mood, K. (2008): Neurotoxic disorders of organophosphorus compounds and their managements. Archives of Iranian medicine, 11, 65-89.

Banday, T. H.; Tathineni, B.; Desai, M. S. \& Naik, V. (2015): Predictors of morbidity and mortality in organophosphorus poisoning: a case study in rural hospital in Karnataka, India. North American journal of medical sciences, 7, 259-261.

Banerjee, I.; Tripathi, S. \& Roy, A. S. (2012):
Clinico-epidemiological characteristics of patients presenting with organophosphorus poisoning. North American journal of medical sciences, 4, 147-151.

Bey, T.; Sullivan, J. \& Walter, F. (2001): Organophosphate and carbamate insecticides. Clinical Environmental Health and Toxic Exposures. Philadelphia: Lippincott William and Wilkins, 2, 1046-1057.

Bilal, M.; Khan, Y.; Ali, S. \& Naeem, A. (2014): The pattern of organophosphorus poisoning and it's short term outcomes in various socioeconomic groups. KJMS, 7, 11-13.

Brahmi, N.; Mokline, A.; Kouraichi, N.; Ghorbel, H.; Blel, Y.; Thabet, H.; Hedhili, A. \& Amamou, M. (2006): Prognostic value of human erythrocyte acetyl cholinesterase in acute organophosphate poisoning. The American journal of emergency medicine, 24, 822-827.

Colak, Ş.; Erdoğan, M. Ö.; Baydin, A.; Afacan, M. A.; Kati, C. \& Duran, L. (2014): Epidemiology of organophosphate intoxication and predictors of intermediate syndrome. Turkish journal of medical sciences, 44, 279-282.

Coskun, R.; Gundogan, K.; Sezgin, G.; Topaloglu, U.; Hebbar, G.; Guven, M. \& Sungur, M. (2015): A retrospective review of intensive care management of organophosphate insecticide poisoning: Single center experience. Nigerian journal of clinical practice, 18, 644-650.

Costa, L. G.; Giordano, G.; Cole, T. B.; Marsillach, J. \& Furlong, C. E. (2013): Paraoxonase 1 (PON1) as a genetic determinant of susceptibility to organophosphate toxicity. Toxicology, 307, 115-122.

Cotton, J.; Lewandowski, P. \& Brumby, S. (2015): Cholinesterase Research Outreach Project (CROP): measuring cholinesterase activity and pesticide use in an agricultural community. BMC public health, 15, 748-752. 
Damalas, C. \& Koutroubas, S. (2016): Farmers' exposure to pesticides: toxicity types and ways of prevention. Multidisciplinary Digital Publishing Institute, 3, 12-17.

Dantoine, T. F.; Debord, J.; Charmes, J.-P.; Merle, L.; Marquet, P.; Lachatre, G. \& Leroux-Robert, C. (1998): Decrease of serum paraoxonase activity in chronic renal failure. Journal of the American Society of Nephrology, 9, 2082-2088.

Darwish, R.; Megahed, H.; Attia, M. \& ElNeily, D. (2017): Paraoxonase 1 gene polymorphism and enzymatic activity as a prognostic marker in cases of poisoning by cholinesterase inhibitor pesticides among Egyptians. Ain Shams Journal of Forensic Medicine and Clinical Toxicology, 28, 88-98.

Eddleston, M.; Haggalla, S.; Reginald, K.; Sudarshan, K.; Senthilkumaran, M.; Karalliedde, L.; Ariaratnam, A.; Sheriff, M. R.; Warrell, D. A. \& Buckley, N. A. (2007): The hazards of gastric lavage for intentional selfpoisoning in a resource poor location. Clinical toxicology, 45, 136-143.

Elgohary, M.; El Ashmawy, N.; El Kelany, R.; Abo Elfadl, A. \& El-Sarnagawy, G. (2013): Comparative Study of Paraoxonase and Cholinestrase Enzymes Activities in Diagnosis of Organophosphorus Insecticide Intoxication. Ain Shams Journal of Forensic Medicine and Clinical Toxicology, 21, 1-11.

Eskenazi, B.; Huen, K.; Marks, A.; Harley, K. G.; Bradman, A.; Barr, D. B. \& Holland, N. (2010): PON1 and neurodevelopment in children from the CHAMACOS study exposed to organophosphate pesticides in utero. Environmental health perspectives, 118, 1775-1781.

Gannur, D.; Maka, P. \& Reddy, K. (2008): Organophosphorus compound poisoning in Gulbarga region-A five year study. Indian Journal of Forensic Medicine \&Toxicology, 2, 3-11.
Ginsberg, G.; Neafsey, P.; Hattis, D.; Guyton, K. Z.; Johns, D. O. \& Sonawane, B. (2009): Genetic polymorphism in paraoxonase 1 (PON1): Population distribution of PON1 activity. Journal of Toxicology and Environmental Health, Part B, 12, 473-507.

Gunduz, E.; Dursun, R.; Icer, M.; Zengin, Y.; Gullu, M. N.; Durgun, H. M. \& Gokalp, O. (2015): Factors affecting mortality in patients with organophosphate poisoning. J Pak Med Assoc, 65, 967-72.

Hassan, N. A. \& Madboly, A. G. (2013): Correlation between serum creatine phosphokinase and severity of acute organophosphorus poisoning: A prospective clinical study (2012-2013). Toxicology And Food Technology, 4, 1829.

Hernández, A.; López, O.; Pena, G.; Serrano, J.; Parrón, T.; Rodrigo, L.; Gil, F. \& Pla, A. (2008): Implications of paraoxonase-1 (PON1) activity and polymorphisms on biochemical and clinical outcomes in workers exposed to pesticides. The paraoxonases: Their role in disease development and xenobiotic metabolism, 3, 221-237.

Hofmann, J. N.; Keifer, M. C.; Furlong, C. E.; De Roos, A. J.; Farin, F. M.; Fenske, R. A.; Van Belle, G. \& Checkoway, H. (2009): Serum cholinesterase inhibition in relation to paraoxonase-1 (PON1) status among organophosphate-exposed agricultural pesticide handlers. Environmental health perspectives, 117, 1402-1408.

Jayaraj, R.; Megha, P. \& Sreedev, P. (2016): Organochlorine pesticides, their toxic effects on living organisms and their fate in the environment. Interdisciplinary toxicology, 9, 90-100.

Jayawardane, P.; Dawson, A. H.; Weerasinghe, V.; Karalliedde, L.; Buckley, N. A. \& Senanayake, N. (2008): The spectrum of intermediate syndrome following acute organophosphate poisoning: a prospective 
cohort study from Sri Lanka. PLoS medicine, 5, e147-e153.

Jokanović, M. \& Stojiljković, M. P. (2006): Current understanding of the application of pyridinium oximes as cholinesterase reactivators in treatment of organophosphate poisoning. European journal of pharmacology, 553, 10-17.

Jørs, E.; Morant, R. C.; Aguilar, G. C.; Huici, O.; Lander, F.; Bælum, J. \& Konradsen, F. (2006): Occupational pesticide intoxications among farmers in Bolivia: a cross-sectional study. Environmental Health, 5, 10-13.

Kavya, S.; Srinivas, V. \& Chandana, M. R. (2012): Clinical profile of patients with organophosphorus poisoning in an intensive care unit in a tertiary hospital. International Journal of Clinical cases and investigations, 4, 24-31.

Kerkvliet, N. \& Lawrence, B. (2010): Cytotoxic $\mathrm{T}$ Cells. Comprehensive Toxicology, Elsevier BV, 5, 109-132.

Kishi, M. (2012): The health impacts of pesticides: what do we now know? The pesticide detox, 3, 45-60.

Lee, J. H.; Lee, Y. H.; Park, Y. H.; Kim, Y. H.; Hong, C. K.; Cho, K. W. \& Hwang, S. Y. (2013): The difference in C-reactive protein value between initial and 24 hours follow-up (D-CRP) data as a predictor of mortality in organophosphate poisoned patients. Clinical toxicology, 51, 29-34.

Magauzi, R.; Mabaera, B.; Rusakaniko, S.; Chimusoro, A.; Ndlovu, N.; Tshimanga, M.; Shambira, G.; Chadambuka, A. \& Gombe, N. (2011): Health effects of agrochemicals among farm workers in commercial farms of Kwekwe district, Zimbabwe. Pan African Medical Journal, 9, 33-37.

Mandour, R. A. (2013): Environmental risks of insecticides cholinesterase inhibitors. Toxicology international, 20, 30-35.

Matthews, A. R.; Sutter, M. E. \& Rentz, D. E. (2011): Serum Paraoxonase-1 (PON-1) Genotype and Exposure to Organophosphorous Insectides-Is There a High-Risk Population? Journal of Medical Toxicology, 7, 243-246.

Mccauley, L. A.; Anger, W. K.; Keifer, M.; Langley, R.; Robson, M. G. \& Rohlman, D. (2006): Studying health outcomes in farmworker populations exposed to pesticides. Environmental health perspectives, 114, 953-960.

Mishra, A.; Shukla, S.; Yadav, M. \& Gupta, A. (2012): Epidemiological study of medicolegal organophosphorus poisoning in central region of Nepal. J Forensic Res, $3,167-171$.

Moffatt, A.; Mohammed, F.; Eddleston, M.; Azher, S.; Eyer, P. \& Buckley, N. A. (2010): Hypothermia and fever after organophosphorus poisoning in humansa prospective case series. Journal of Medical Toxicology, 6, 379-385.

Muley, A.; Shah, C.; Lakhani, J.; Bapna, M. \& Mehta, J. (2014): To identify morbidity and mortality predictors in acute organophosphate poisoning. Indian journal of critical care medicine: peerreviewed, official publication of Indian Society of Critical Care Medicine, 18, 297-301.

Panuwet, P.; Prapamontol, T.; Chantara, S. \& Barr, D. B. (2009): Urinary pesticide metabolites in school students from northern Thailand. International journal of hygiene and environmental health, 212, 288-297.

Parul, G.; Kapil, G.; Surjit, S.; Ashish, B.; Navneet, S. \& Gill, K. (2012): Role of paraoxonases in detoxification of organophosphates. JARBS, 4, 320-325.

Patel, D. J. \& Tekade, P. R. (2011): Profile of organophosphorus poisoning at Maharani Hospital, Jagdalpur, Chhattisgarh: a three years study. $\mathrm{J}$ indian acad forensic med, 33, 102-105.

Paul, D.; Reis, S. E.; Kammerer, C. M.; Mcnamara, D. M.; Holubkov, R.; Sharaf, B. L.; Sopko, G.; Pauly, D. F.; Merz, C. N. B. \& Kamboh, M. I. (2003): Association between the severity of angiographic coronary artery disease and paraoxonase gene polymorphisms in the 
National Heart, Lung, and Blood Institute-sponsored Women's Ischemia Syndrome Evaluation (WISE) Study. The American Journal of Human Genetics, 72, 13-22.

Peter, J. V.; Sudarsan, T. I. \& Moran, J. L. (2014): Clinical features of organophosphate poisoning: A review of different classification systems and approaches. Indian journal of critical care medicine: peer-reviewed, official publication of Indian Society of Critical Care Medicine, 18, 735-737.

Priyadarsini, C. I.; Rao, S. B. \& Sarma, M. (2015): Assessment of severity, treatment and outcome of organophosphorus poisoning: A descriptive study. $\mathrm{J}$ of Evidence Based Med \& Hlthcare, 2, 31943204.

Rahul, H. N., D; Nusrath, A.; Rajeshwari, A. \& Rani, N. A. (2017): Utility of Serum Paraoxonase Levels with reference to Severity of Organophosphorus Poisoning. Indian Journal of Medical Biochemistry, 21, 101-105.

Rehiman, S.; Lohani, S. \& Bhattarai, M. (2008): Correlation of serum cholinesterase level, clinical score at presentation and severity of organophosphorous poisoning. J Nepal Med Assoc, 47, 47-52.

Richard, S. A.; Frank, E. A. \& D'souza, C. J. (2013): Correlation between cholinesterase and paraoxonase 1 activities: case series of pesticide poisoning subjects. BioImpacts: BI, 3, 119-123.

Sam, K. G.; Kondabolu, K.; Pati, D.; Kamath, A.; Kumar, G. P. \& Rao, P. G. (2009): Poisoning severity score, APACHE II and GCS: effective clinical indices for estimating severity and predicting outcome of acute organophosphorus and carbamate poisoning. Journal of forensic and legal medicine, 16, 239-247.

Shah Harsh, D.; Prakash, M. \& Ram, O. (2012): Acute organophosphorus poisoning and clinical admission score association among patients admitted in emergency ward of a tertiary teaching hospital of medical college. J Pharm Biomed Sci, 17, 1-5.

Soltaninejad, K. \& Shadnia, S. (2014): History of the use and epidemiology of organophosphorus poisoning. Basic and Clinical Toxicology of Organophosphorus Compounds, 9, 25-43.

Sözmen, E.; Mackness, B.; Sözmen, B.; Durrington, P.; Girgin, F.; Aslan, L. \& Mackness, M. (2002): Effect of organophosphate intoxication on human serum paraoxonase. Human \& experimental toxicology, 21, 247-252.

Sumathi, M.; Kumar, S. H.; Shashidhar, K. \& Takkalaki, N. (2014): Prognostic significance of various biochemical parameters in acute organophosphorus poisoning. Toxicology international, 21, 167-171.

Tanrisev, M. \& Toprak, Ö. (2004): The relationship of clinical signs with therapy and biochemical parameters in patients with organophosphate intoxication. European Journal of General Medicine, 1, 32-37.

Timchalk, C. (2010): Biomonitoring of pesticides: pharmacokinetics of organophosphorous and carbamate insecticides. Anticholinesterase Pesticides: Metabolism, Neurotoxicity, and Epidemiology. 1st John Wiley and Sons, 6, 267-287.

Tripathi, S. (2014): Prognostic value of glasgow coma scale, poisoning severity score and serum acetylcholinesterase levels in organophosphorus poisoning. Journal of Evolution of Medical and Dental Sciences, 3, 3415-3422.

Vijayakumar, S.; Fareedullah, M.; Kumar, E. A. \& Rao, K. M. (2011): A prospective study on electrocardiographic findings of patients with organophosphorus poisoning. Cardiovascular toxicology, 11, 113-117.

Z'gambo, J.; Siulapwa, Y. \& Michelo, C. (2016): Pattern of acute poisoning at two urban referral hospitals in Lusaka, 
Zambia. BMC emergency medicine, 16, 2-6.

Zhang, W.; Jiang, F. \& Ou, J. (2011): Global pesticide consumption and pollution: with China as a focus.
Proceedings of the International Academy of Ecology and Environmental Sciences, 1, 125-126. 


\section{الملخص العربى}

القيمة التتبوئية لنوع المبيد الحشري والأنشطة الأنزيمية لثدة التسمم الحاد بالمبيدات الحشرية

$$
\begin{aligned}
& \text { وفاء محمد عبد المنعم، محمد حسام الدين مغربى ، سالى يحيى عبد الحميد ، غادة على عمران، دعاء محمد المظ }
\end{aligned}
$$

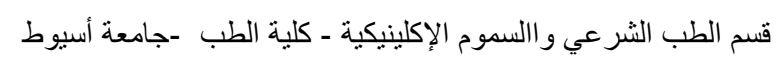

$$
\begin{aligned}
& \text { قسم الباطنة العامة - كلية الطب -جامعة أسيوط }
\end{aligned}
$$

يعتبر التسمم بالمبيدات الحشرية هو المسؤول عن الأمراض الخطيرة في جميع أنحاء العالم وخاصة في البلدان النامية بما في ذلك مصر • حتى الان لا نوجد أية علامات واضحة للتتبؤ او لتصنيف شدة التسمم الحاد بالمبيدات الحشرية. حيث ان صعوبة تحديد جرعة ونوع المبيد الذي تم ابتلاعه يجعل نتائج التبؤ غير دقيقة . هدفت هذه الدراسة إلى التعرف على المبيدات الحشرية الثائعة وتقديرها في المرضى الذين يعانون من التسمم الحاد بها فى مستشفيات جامعة أسيوط - 2 .الكثف عن مستويات الباراكوزنيز والكولينستراز في المرضى هده المصابين بالتسمم -3 .تقييم القيمة التتبؤية لنوع المبيدات ومستوى الإنزيمات بالنسبة لثدة التسمم بالمبيدات الحشرية. ولقد اظهرت نتائج هذه الدراسة ان معظم المصابين كانوا من الثباب الذكور ويقيمون في المناطق بإن الريفية. كان التسمم عرضيًا بشكل أساسي عن طريق الفم (66٪). ولقد ارتبط انخفاض ضغط الدم وارتفاع عدد دقات القلب وارتفاع معدل التفس بشدة التسمم بالمبيدات الحشرية الفسفورية ـولقد اظهرت الدراسة وجود اكثر من نوع من المبيد فى دم المرضى وكان اكثرهم انتشارا هو المبيدات الحشرية الفسفورية على وجه التحديد الملاثثون. وتخلص هذه الدراسة إلى أن المرضى الذين لايهم نشاط الباراكزونيز ا وكولينستراز عالى قد يكونوا اقل قابلية للتسمم بالمبيدات الحشرية وربما لهم فرصة اعلى للتقليل من الأثار السلبية السمية للمبيدات الحشرية. 